\title{
Organic carbon decomposition, primary and bacterial productivity, and sulphate reduction, in tropical seagrass beds of the Gulf of Carpentaria, Australia
}

\author{
Peter C. Pollard, D. J. W. Moriarty \\ CSIRO Marine Laboratories, PO Box 120, Cleveland, Queensland 4163, Australia
}

\begin{abstract}
The oxidation of organic carbon by bacteria in tropical seagrass communities was studied in austral summer 1986-87. The major seagrass species were Enhalus acoroides, Syringodium isoetifolium, Cymodocea serrulata, Thalassia hemprichii and Cymodocea rotundata. Seagrass gross productivity, determined by a lacunal gas technique, ranged from 0.5 to $4.3 \mathrm{~g} \mathrm{C} \mathrm{m}^{-2} \mathrm{~d}^{-1}$. In comparison, gross community productivity, measured from diurnal changes in $\mathrm{O}_{2}$ concentration in the water column, ranged from 4 to $9 \mathrm{~g} \mathrm{C} \mathrm{m}^{-2} \mathrm{~d}^{-1}$. Macroalgae, epibenthic and epiphytic algae made the major contribution to gross primary production in the communities studied, contributing 40 to $90 \%$ of gross primary production. Most of the primary production was utilized by hydrolytic and fermentative bacteria and was ultimately oxidized by sulphate-reducing bacteria. Hydrolytic (aerobic) and fermentative bacterial productivity, determined from rates of incorporation of tritiated thymidine into DNA, ranged from 3 to $13 \mathrm{~g} \mathrm{C} \mathrm{m}^{-2} \mathrm{~d}^{-1}$ (integrated over a depth of $12 \mathrm{~cm}$ in the sediment). The highest rates of sulphate reduction, determined with ${ }^{35} \mathrm{~S}$, coincided with the below-ground distribution of seagrass roots and rhizomes. Between 1.7 and $2.2 \mathrm{~g} \mathrm{C} \mathrm{m}^{-2} \mathrm{~d}^{-1}$ was oxidized to $\mathrm{CO}_{2}$ by the sulphate-reducing bacteria; this is equivalent to 30 to $80 \%$ of the net community productivity.
\end{abstract}

\section{INTRODUCTION}

The bacterial community of coastal environments plays very important role in oxidizing complex organic compounds and remineralizing the nutrients essential to sustaining primary production (Boynton \& Kemp 1985, Moriarty et al. 1985, Alongi 1988). Seagrass meadows are a significant component of these coastal environments in the Gulf of Carpentaria and are essential to the maintenance of a commercial fishery for penaeid prawns (Staples 1985, Poiner et al. 1987).

The large input or organic matter into seagrass-bed sediments leads to a large consumption of oxygen by the benthic microbial community (Moriarty 1986). The anaerobic conditions that result from the activity of fermentative bacteria in seagrass sediment, and the high concentration of sulphate in seawater, provide an ideal environment for sulphate-reducing bacteria; methanogenesis is less important (Moriarty et al. 1985, Skyring 1987). Anaerobic dissimilatory sulphate reduction is then the major pathway by which organic carbon is ultimately oxidized and nutrients are remineralised in marine sediments (Jørgensen 1982, Howarth 1984, Skyring 1987, Canfield 1989).

The importance of carbon and sulphur cycling in some coastal habitats has long been recognised in Spartina beds (Howarth \& Teal 1979), cyanobacterial mats (Skyring 1987), and seagrass communities (Moriarty et al. 1985), yet very little work has been done on the relationship between the macrophytes, sediment geochemistry, and the bacterial community of seagrass beds. Sulphate-reducing bacteria have been shown to oxidize much of the carbon that is fixed during photosynthesis (Howarth \& Teal 1979, Jørgensen 1982, Skyring 1987).

Sulphate-reducing bacteria maintain the appropriate geochemical conditions in the sediment, on which seagrasses depend. Phosphate, nitrate and sulphate cycles are all inextricably related to each other in sediments; for example, sulphate-reducing bacteria control phosphate release from sediment (Craven \& Hayasaka 1982, Valiela 1984, Caraco et al. 1989), creating the 
reduced environment for nitrogen fixation processes (Howarth et al. 1988a, b).

It is only recently that methods have been developed to quantify simultaneously the primary productivity and the activity of aerobic and anaerobic heterotrophic bacteria involved in carbon cycling in marine sediments (Moriarty 1986, Roberts \& Moriarty 1987, Pollard 1987, Skyring 1987, Moriarty \& Pollard 1990). The flux of organic carbon needed to support the growth of hydrolytic and fermentative bacteria can be determined from the rate of tritiated thymidine incorporation into DNA. The sulphate-reducing bacteria do not incorporate thymidine into DNA (Moriarty 1986); their contribution can be quantified separately with ${ }^{35} \mathrm{~S}$ (Skyring 1988). In this study we have quantified the contribution of organic carbon in seagrass sediments from primary producers, to its oxidation by hydrolytic, fermentative and sulphate-reducing bacteria, on a daily basis.

\section{MATERIALS AND METHODS}

Site description. Study sites were chosen to represent the different geomorphology and seagrass communities of the Gulf of Carpentaria (Fig. 1). The climate is monsoonal, with rain occurring mostly between December and April. One week before the study on Groote Eylandt, February 1987, cyclone 'Jason' passed close by. Its central pressure was $970 \mathrm{hPa}$ and wind speeds were $130 \mathrm{~km} \mathrm{~h}^{-1}$; the highest rainfall for the previous $20 \mathrm{yr}$ was recorded in that week.

Three sites were studied at Groote Eylandt, a continental island with geomorphology similar to that of the nearby mainland. The first sampling site, an open bay that was exposed to the effects of the cyclone, was dominated by 2 species of seagrass, Syringodium isoetifolium (Aschers.) Dandy and Cymodocea serrulata. (R. Br.) Aschers. et Magnus; this is the site group F described by Poiner et al. (1987). Most of the belowground plant biomass was in the top $10 \mathrm{~cm}$ of a silty clay sediment (Moriarty et al. 1990), and there were no macroalgae in this sampling site. The second sampling site was a reef flat fringed on the landward side by mangroves and on the seaward side by a coral reef; macroalgae comprised a substantial proportion of its plant biomass. The seagrasses Thalassia hemprichii (Ehrenb.) Aschers. and Cymodocea rotundata Ehrenb. et Hempr. ex Ashers. were present [described by Poiner et al. (1987) as site group C]. The sediment was a muddy silt with some coral rubble and was 4 to $7 \mathrm{~cm}$ deep, on a hard calcareous substratum. The third site was a sheltered bay, with a monospecific stand of Enhalus acoroides [described by Poiner et al. (1987) as site D] in a coarse, sandy sediment with shell fragments. These 3 study sites are referred to in this study as the 'open bay', 'reef flat' and 'sheltered bay', respectively (Fig. 1).

The 2 study sites at the Embley River, Weipa, both had muddy silt-clay sediments. One site was a mud flat next to a mangrove forest, but without macrophytes; the other was a seagrass flat on which Enhalus acoroides (L. F.) Royle was predominant, with some Halodule uninervis (Forsk.) Aschers. in Boissier, Halophila ovalis (R. Br.) Hook. F., and unidentified macroalgae. These are the sites 5 and 1, respectively, described by Staples et al. (1985); these sites will be referred to as the mud flat and the seagrass flat, respectively.

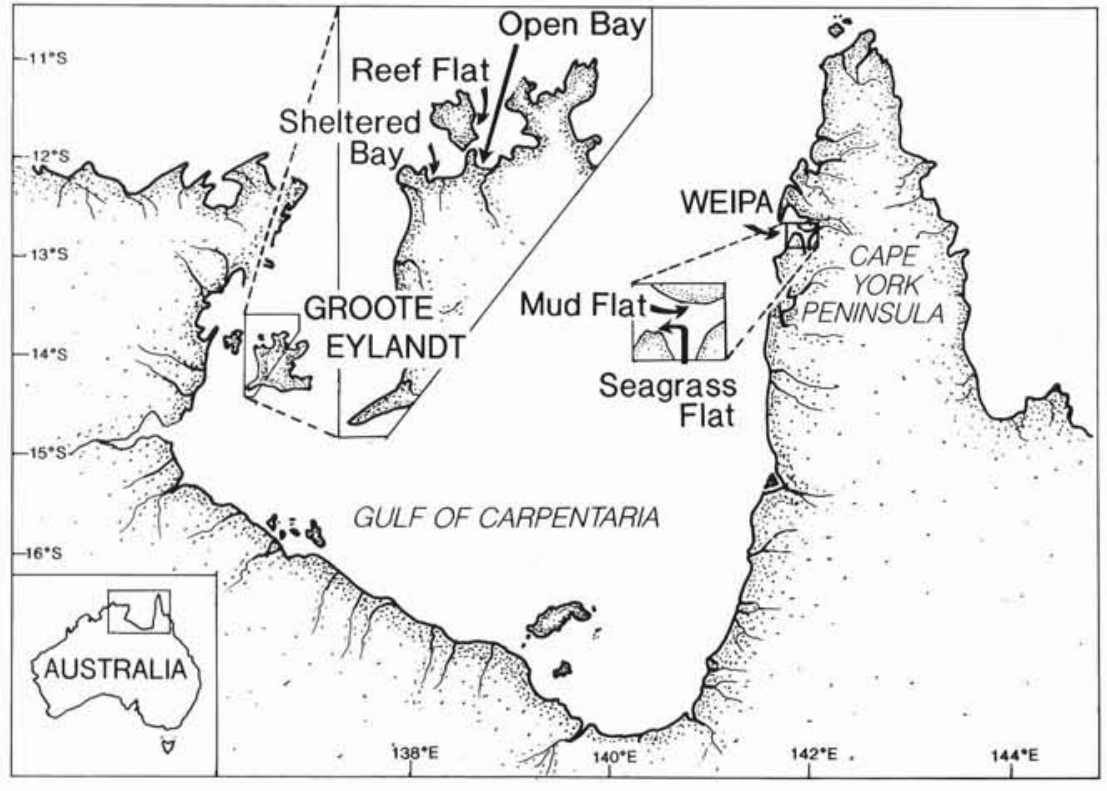

Fig. 1. Study sites on Groote Eylandt and at Weipa, Australia 
The studies were done in November 1986 at Weipa and in February 1987 at Groote Eylandt. Water temperatures varied from 31 to $32{ }^{\circ} \mathrm{C}$ at Weipa and from 27 to $30^{\circ} \mathrm{C}$ at Groote Eylandt.

Biomass and shoot density. Replicate cores $(10 \mathrm{~cm}$ diam.) of seagrass shoots, rhizomes, roots and sediments were collected to a depth of $30 \mathrm{~cm}$ in the Enhalus acoroides communities; to a depth of $12 \mathrm{~cm}$ in the Syringodium isoetifolium and Cymodocea serrulata communities; and to the full depth in the reef flat ( 5 to $7 \mathrm{~cm}$ ) in the Thalassia hemprichii and Cymodocea rotundata communities. For each community, shoot density was measured and above-ground plant material removed and separated into seagrass species. Rhizomes and roots were sieved out from sediment and separated into species., All plant material was dried at $105{ }^{\circ} \mathrm{C}$ and weighed.

\section{Primary productivity}

Community productivity. Gross community productivity and respiration were determined from changes in the oxygen concentration of water flowing over the seagrass bed, using the diel curve procedure described by Odum \& Hoskin (1958). All temperatures and oxygen concentrations were measured by a submersible electrode that produces oxygen at the same rate that it is consumed (Leeds and Northrup, Model 8500).

Seagrass productivity. The photosynthetic rates of the seagrasses were determined with a lacunal gas technique (Roberts \& Moriarty 1987). Gas release was measured by attaching shoots of seagrass to a pipette (10 $\mathrm{ml}$ for Enhalus acoroides; $1 \mathrm{ml}$ for other species) in place of the rhizome. The shoots were returned to the seagrass bed and exposed to natural light, temperature and water movement. Seagrasses were brought to the surface for gas volume measurement. Calibration of the lacunal gas method for Syringodium isoetifolium and Cymodocea serrulata has been reported elsewhere (Roberts \& Moriarty 1987). E. acoroides was calibrated as part of this study, using the method described by Roberts \& Moriarty (1987). Lacunal gas was $12.6 \pm 0.6 \%(\mathrm{SE}, \mathrm{n}=4)$ of total oxygen released during photosynthesis. Oxygen was $29.7 \pm 0.8 \%(n=9)$ of lacunal gas. For this work, it was assumed that the gas composition in the lacunae of the other species was the mean of that in Zostera capricorni, S. isoetifolium and C. serrulata, viz. $33.6 \%$ oxygen (range 32.2 to 34.3 ) (Roberts \& Moriarty 1987). Gross seagrass productivity in terms of carbon was calculated from the values for oxygen production, assuming a 1:1 molar ratio (Roberts \& Moriarty 1987).

The values for shoot productivity and shoot density were used to calculate the productivity of the study areas.

\section{Bacterial productivity}

Hydrolytic and fermentative bacterial productivity. The rate of bacterial division was determined from the rate at which tritiated thymidine was incorporated into DNA. The filtration method, as outlined by Moriarty \& Pollard (1990), was used to separate the radioactively labelled bacterial DNA from the unincorporated isotope. [Methyl- ${ }^{3} \mathrm{H}$ ] thymidine (specific activity: 0.92 TBq $\mathrm{mmol}^{-1}\left(25 \mathrm{Ci} \mathrm{mmol}^{-1}\right)$ in a sterile aqueous solution of $2 \%$ ethanol) was purchased from Commissariat à l'Energie Atomique, Sarclay, France, and diluted to specific activity of $370 \mathrm{GBq} \mathrm{mmol}{ }^{-1}$ before use.

The sediment was collected to a maximum depth of $30 \mathrm{~cm}$ with a PVC plastic water pipe (ca $30 \mathrm{~mm}$ i.d.), which could be plugged at both ends with disposable $50 \mathrm{ml}$ syringe plungers. The sediment was extruded and the top $1 \mathrm{~mm}$ scraped off, dropped into a $12 \mathrm{ml}$ polycarbonate test tube containing $3 \mathrm{ml}$ of filtered seawater, and mixed briefly. The next $10 \mathrm{~mm}$ was extruded and stored frozen for dry weight determination. The relationship between the sediment volume and dry weight was used to relate bacterial productivity to sediment surface area at each depth interval. The $30 \mathrm{~cm}$ core was further extruded and $1 \mathrm{~mm}$ of sediment again scraped off, dropped into a $12 \mathrm{ml}$ polycarbonate test tube containing $3 \mathrm{ml}$ of filtered seawater, and mixed briefly. The above process was repeated with the full length of the core.

Portions of the sediment slurry $(100 \mu \mathrm{l}$, ca $0.03 \mathrm{~g}$ dry wt each) were subsampled into $12 \mathrm{ml}$ polycarbonate tubes; 2 were used as blanks, 3 as tests for the thymidine method, and 2 for counting bacteria. The incubation was started by adding $462.5 \mathrm{kBq}$ of [methyl$\left.{ }^{3} \mathrm{H}\right]$ thymidine to the sediment slurry subsample. The samples were incubated in the shade at ambient water temperature. Ethanol $\left(80 \%, \mathrm{v} / \mathrm{v}\right.$ containing $100 \mathrm{mg} \mathrm{l}^{-1}$ thymidine) was added to stop the incubations. The samples were taken to the laboratory, where the radioactively labelled bacterial DNA was separated from the unincorporated tritiated thymidine by filtration (Moriarty \& Pollard 1990). Blanks were prepared by adding ethanol immediately after addition of the tritiated thymidine to the sediment.

In the field work described here, the slurry method was the most appropriate technique. The thymidine was rapidly and evenly mixed throughout the sediment sample, and the number of bacteria was assessed in the same sediment that was to be used for the determination of rates of tritiated thymidine incorporation into DNA. We have shown elsewhere that, with a short incubation period, there is little difference in the results given by this method and by a core injection technique where the sediment sample was incubated undisturbed under anaerobic conditions (Moriarty \& Pollard 1990). 
Comparative studies of bacterial productivity and carbon transfer are difficult where there is variation due to patchiness in the distribution of bacteria. Thus, rates of bacterial DNA synthesis and bacterial numbers were measured on subsamples from the same sediment slurry, and the results were expressed as specific growth rates (productivity divided by bacterial numbers) rather than as productivity alone. The bacteria were stained with acridine orange, counted, and their sizes measured using epifluorescence microscopy (Hobbie et al. 1977). The average carbon content of bacteria was $40 \mathrm{fg} \mathrm{cell}^{-1}$, based on a factor of

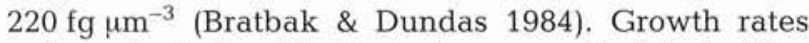
and productivity of the bacteria were calculated with a conversion factor of $5 \times 10^{17}$ cells produced per mole of thymidine incorporated (Moriarty 1988).

Sampling sites were chosen at random, and the experiments were designed so that the time depth sampling regimes were orthogonal within each site. Differences due to time of day and depth in the sediment were examined by analysis of variance (ANOVA) on log-transformed values of radioactivity (disintegrations per minute: dpm) in DNA (i.e. bacterial productivity), of numbers of bacteria per core, of specific growth rates (productivity divided by numbers) and, for the rates of sulphate reduction, of the dpm in sulphide. This transformation was chosen so as to normalise the results and improve the homogeneity of the variances. Depth and time effects were tested against their interaction when the interaction exceeded the error variation between cores. Student-Newman-Keuls tests were used to examine differences between means.

The efficiency with which radioactively labelled DNA was extracted was determined with a bacterial culture that was labelled with tritiated thymidine and prepared as described by Pollard (1987). Recovery of the cultured bacteria, added to samples of sediment on polycarbonate filters, ranged from 60 to $90 \%$, and the results were corrected with these factors. Isotope dilution experiments were conducted on each different sediment type, as described by Pollard \& Moriarty (1984). No isotope dilution was apparent.

\section{Sulphate reduction}

The method for determining rates of sulphate reduction has been described in detail by Skyring (1988). Sodium $\left[{ }^{35} \mathrm{~S}\right]$ sulphate $\left(\mathrm{Na}_{2}{ }^{35} \mathrm{SO}_{4}\right)$, with a specific activity of $2.9 \mathrm{GBq} \mathrm{mmol}{ }^{-1}\left(78.4 \mathrm{mCi} \mathrm{mmol}^{-1}\right)$ at the time of despatch, was purchased from Amersham, Australia Pty Ltd, and used within 2 mo of the despatch date. A solution of radioactive sulphate $(92.5 \mathrm{MBq})$ was made in $2 \mathrm{ml}$ of sodium silicate (final concentration: $2.5 \%$ $(\mathrm{w} / \mathrm{v})) ; 10 \mu \mathrm{l}$ of this solution was spotted onto a glass rod
(5 $\mathrm{cm}$ long, $1 \mathrm{~mm}$ diameter, previously washed with acetone). This process was done under a drying lamp.

Sediment was collected to a maximum depth of $30 \mathrm{~cm}$ with a PVC plastic water pipe (ca $30 \mathrm{~mm}$ i.d.), which could be sealed at the bottom with a disposable $50 \mathrm{ml}$ syringe plunger. A $10 \mathrm{ml}$ syringe, with the end cut off, was inserted $50 \mathrm{~mm}$ into the sediment in the PVC pipe. With the sediment and $10 \mathrm{ml}$ syringe still in place, the larger $300 \mathrm{~mm}$ core was extruded until the $10 \mathrm{ml}$ syringe cleared the top of the water pipe. A glass rod, carrying the $\mathrm{Na}_{2}{ }^{35} \mathrm{SO}_{4}$, was inserted longitudinally and the syringe sealed at both ends (Skyring et al. 1983). This process was repeated every $50 \mathrm{~mm}$ down the $30 \mathrm{~cm}$ core. The samples were incubated at ambient seawater temperatures for $6 \mathrm{~h}$, then $1 \mathrm{ml}$ of saturated zinc acetate solution was injected centrally throughout the core, which was then frozen and taken to the laboratory for analysis. The radioactivity in the acid-volatile sulphide (AVS) and non-acid-volatile sulphide (NAVS) was measured.

Acid-volatile sulphide distillation. The frozen sediment sample was directly injected into the reaction flask of the distillation apparatus, which contained $60 \mathrm{ml}$ of $2 \mathrm{M} \mathrm{H}_{2} \mathrm{SO}_{4}$ and $0.2 \mathrm{ml}$ of an anti-foaming agent (Dow Corning Antifoaming $\mathrm{C}$ Emulsion). The apparatus was kept under positive pressure with gaseous nitrogen, which was deoxygenated by passing it through a solution of methyl viologen. The sample was refluxed for $40 \mathrm{~min}$, and $\mathrm{H}_{2} \mathrm{~S}$ was collected in 2 traps containing $30 \mathrm{ml}$ of $2 \mathrm{M} \mathrm{NaOH}$. Of the $\mathrm{NaOH}$ solution, $0.5 \mathrm{ml}$ was placed in a scintillation vial containing $4 \mathrm{ml}$ water, to which was added $5 \mathrm{ml}$ scintillation fluid (Ready-Solv MP, purchased from Beckman Inc., Galway, Ireland). The radioactivity was measured the following day, after chemiluminescence had decayed.

Non-acid-volatile sulphide distillation. After the AVS was removed from the sediment, the $\mathrm{NaOH}$ traps were replaced. Other forms of sulphide that remained in the sediment, such as pyrite $\left(\mathrm{FeS}_{2}\right)$, were reduced by refluxing for $60 \mathrm{~min}$ with $5 \mathrm{~g}$ of granulated tin and $30 \mathrm{ml}$ of $20 \%$ (w/v) $\mathrm{SnCl}_{2}$ in concentrated $\mathrm{HCl}$ (Skyring 1988). The $\mathrm{NaOH}$ traps were again sampled $(0.5 \mathrm{ml})$ and the radioactivity measured as described above.

A ratio of $2: 1$ for the carbon oxidised to the sulphate reduced was used to calculate the amount of organic carbon required to support the measured rates of sulphate reduction, because in most marine environments acetate is the most likely substrate used by sulphatereducing bacteria (Skyring 1987). The specific activity of the $\mathrm{Na}_{2}{ }^{35} \mathrm{SO}_{4}$ in situ was calculated from the sulphate concentration in interstitial water.

Sulphate in interstitial water. The interstitial water was separated from a $50 \mathrm{~mm}$ sediment sample, collected with a $30 \mathrm{~mm}$ diameter core by centrifuging it at 
$6000 \times \mathrm{g}$ for $10 \mathrm{~min}$. The sediment pellet was resuspended in $10 \mathrm{ml}$ of water (Milli-RQ, Millipore Corporation, USA). This process was repeated twice and the supernatant solutions were pooled. The solution was analysed for sulphate by chemically suppressed ion chromatography using a DIONEX 2000 psi system (Linbrook International), with an AS 4A separator column and suppressed conductivity detection, according to a modified version of EPA-600/4-84-017 technique.

\section{RESULTS}

\section{Plant biomass and productivity}

Algae were major primary producers (Table 1), as the gross primary productivity of the whole community nearly always exceeded the gross seagrass productivity.

On the seagrass flat at Wiepa, the above- and belowground biomass was dominated by Enhalus acoroides
(Table 2). Most of the root and rhizome biomass was in the top $10 \mathrm{~cm}$, although some did penetrate to $30 \mathrm{~cm}$. The other seagrasses and macroalgae comprised about $20 \%$ of the total biomass (Table 2). The primary productivity of the whole community at Weipa was 4 times greater than that of $E$. acoroides alone, indicating that the algae were substantial contributors (Table 1). These observations were in contrast to the sheltered bay at Groote Eylandt, where there was a monospecific stand of $E$. acoroides which had 3 times the shoot density of that at Weipa and which contributed $60 \%$ of gross community primary productivity $\left(5 \mathrm{~g} \mathrm{C} \mathrm{m}^{-2} \mathrm{~d}^{-1}\right.$; Table 1).

On the reef flat, the seagrasses Cymodocea rotundata and Thalassia hemprichii were sparsely distributed, and they contributed only $13 \%$ of gross primary productivity $\left(6 \mathrm{~g} \mathrm{C} \mathrm{m}^{-2} \mathrm{~d}^{-1}\right)$. In the open bay study area, seagrasses (C. serrulata and Syringodium isoetifolium) were denser and contributed about $40 \%$ of gross primary productivity $\left(9 \mathrm{~g} \mathrm{C} \mathrm{m}^{-2} \mathrm{~d}^{-1}\right.$.

The oxygen concentration in the water column was

Table 1. Shoot density and primary productivity of the seagrasses and of the whole community at Weipa and Groote Eylandt.

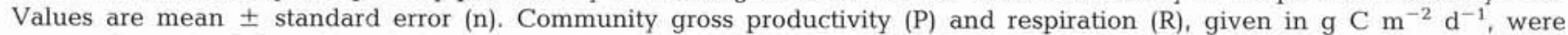
determined from diurnal changes in oxygen concentration $\left(\mathrm{mg} \mathrm{O}_{2} \mathrm{l}^{-1}\right)$ in water, for which the ranges are shown

\begin{tabular}{|c|c|c|c|c|c|c|c|}
\hline \multirow{2}{*}{$\begin{array}{l}\text { Site } \\
\text { Species }\end{array}$} & \multirow{2}{*}{$\begin{array}{c}\text { Shoot } \\
\text { density } \\
\left(\text { No. } \mathrm{m}^{-2}\right)\end{array}$} & \multicolumn{2}{|c|}{ Seagrass productivity } & \multicolumn{2}{|c|}{ Community } & \multicolumn{2}{|c|}{ Oxygen } \\
\hline & & $\left(\mathrm{mg} \mathrm{C}\right.$ shoot $\left.^{-1} \mathrm{~d}^{-1}\right)$ & $\left(\mathrm{g} \mathrm{C} \mathrm{m}^{-2} \mathrm{~d}^{-1}\right)$ & $\stackrel{\mathrm{P}}{\left(\mathrm{g} \mathrm{C} \mathrm{m}^{-}\right.}$ & $\begin{array}{c}\mathrm{R} \\
-2 \mathrm{~d}^{-1} \mathrm{~J}\end{array}$ & $\begin{array}{l}\text { Max. } \\
\text { (mg O }\end{array}$ & Min. \\
\hline \multicolumn{8}{|l|}{ Weipa: } \\
\hline Enhalus acoroides & $20 \pm 3 \quad$ (15) & $26 \pm 4 \quad(7)$ & 0.9 & 4.0 & & 7.2 & 2.8 \\
\hline \multicolumn{8}{|l|}{ Groote Eylandt: } \\
\hline $\begin{array}{l}\text { Sheltered bay: } \\
\text { Enhalus acoroides }\end{array}$ & $70 \pm 3$ & $45 \pm 4$ & 3.1 & 5.0 & 3.0 & 7.0 & 3.5 \\
\hline \multicolumn{8}{|l|}{ Open bay: } \\
\hline $\begin{array}{l}\text { Syringodium } \\
\text { isoetifolium } \\
\text { Cymodocea serrulata } \\
\text { Total }\end{array}$ & $\begin{array}{l}2700 \pm 370(14) \\
1100 \pm 165(14)\end{array}$ & $\begin{array}{l}0.5 \pm 0.1(4) \\
2.7 \pm 0.5(4)\end{array}$ & $\begin{array}{l}1.3 \\
\\
3.0 \\
4.3\end{array}$ & 9.0 & 11.0 & 14.0 & 0.5 \\
\hline \multicolumn{8}{|l|}{ Reef flat: } \\
\hline $\begin{array}{l}\text { Cymodocea rotundata } \\
\text { Thalassia hemprichii } \\
\text { Total }\end{array}$ & $\begin{array}{l}620 \pm 140(8) \\
560 \pm 160(8)\end{array}$ & $\begin{array}{l}0.8 \pm 0.1 \\
0.5 \pm 0.01(4)\end{array}$ & $\begin{array}{l}0.5 \\
0.3 \\
0.8\end{array}$ & 6.0 & 5.0 & 6.5 & 2.2 \\
\hline
\end{tabular}

Table 2. Biomass of macrophytes at Weipa. Means and standard error and number of replicates (n) are shown

\begin{tabular}{|lrcrrc|}
\hline Species & $\mathrm{n}$ & $\begin{array}{c}\text { Shoot density } \\
\left(\text { No. } \mathrm{m}^{-2} \pm \mathrm{SE}\right)\end{array}$ & $\begin{array}{c}\text { Above-ground biomass } \\
\left(\mathrm{g} \mathrm{m}^{-2} \pm \mathrm{SE}\right)\end{array}$ & $\begin{array}{c}\text { Root biomass } \\
\text { Depth }(\mathrm{cm})\end{array}$ & $\left(\mathrm{g} \mathrm{m}^{-2} \pm \mathrm{SE}\right)$ \\
\hline Enhalus acoroides & 15 & $20 \pm 3$ & $42 \pm 6$ & 30 & $174 \pm 20$ \\
Halodule uninervis & 4 & $370 \pm 185$ & $3 \pm 1$ & 10 & 3 \\
Halophila ovalis & 6 & $320 \pm 57$ & $3 \pm 1$ & 10 & 3 \\
Macroalgae & 3 & & $10 \pm 9$ & & \\
\hline
\end{tabular}


highest around midday and lowest at dawn. The range in concentration was greater in the open bay than at the other sites (Table 1).

\section{Hydrolytic and fermentative bacterial productivity}

Bacterial productivity was very high at the open bay site at Groote Eylandt, with an average of $10 \mathrm{~g} \mathrm{C} \mathrm{m}^{-2}$ $\mathrm{d}^{-1}$ integrated over $12 \mathrm{~cm}$ depth, and $2 \mathrm{~g} \mathrm{C} \mathrm{m}^{-2} \mathrm{~d}^{-1}$ in the top $1 \mathrm{~cm}$ of sediment (Fig. 2). Productivity was highest in the upper $6 \mathrm{~cm}$ of sediment (the main root zone of the seagrasses), decreasing significantly below $10 \mathrm{~cm}$ depth (Table 3, Fig. 2). An ANOVA on data from the main root and rhizome zone of the sediment $(0$ to $10 \mathrm{~cm}$ ) showed that time of day accounted for more of the variance than did depth (Table 3 ). This was due to a significantly large increase in productivity near the surface in the late morning. At $30 \mathrm{~cm}$, i.e. below the root zone, there was no significant diel variation in bacterial production. In these samples, the numbers of bacteria did not vary significantly with time of day within a given depth zone in the sediment (Fig. 3).

On the reef flat, bacterial productivity was higher at the surface than below it (Fig. 2, Table 3). The sediment on the flat is shallower $(7 \mathrm{~cm})$ than at the other sites, and the influence of the seagrass roots is limited to this narrow band of sediment. The productivity and specific growth rates of the bacteria were greatest at

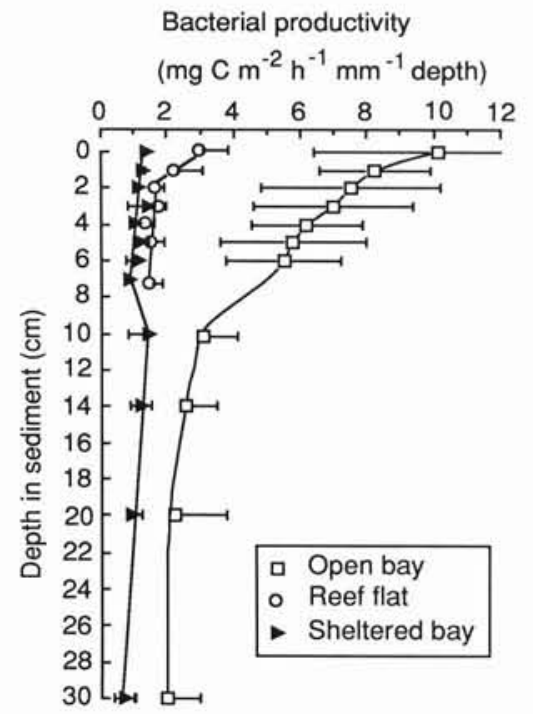

Fig. 2. Bacterial net productivity in sediment at the Groote Eylandt study sites. Values are means for the $24 \mathrm{~h}$ period with standard error bars $(n=3)$. Where no error bars are shown they are within the size of the symbol

10:00 h (Fig. 4), a result similar to that found for the open bay site.

In the Enhalus acoroides bed in the sheltered bay at Groote Eylandt, bacterial productivity did not vary significantly with depth (Table 3, Fig. 2). The diel variation in specific growth rates was more obvious at 3 and

Table 3. Analyses of variance in bacterial productivity and specific growth rates (bacterial productivity divided by bacterial numbers) in sediment, due to time of day and depth in the sediment, at the 3 Groote Eylandt sites and 2 Weipa sites. Means of values for 3 replicate cores were analysed at each time of day. n: number of samples for each site; df: degrees of freedom

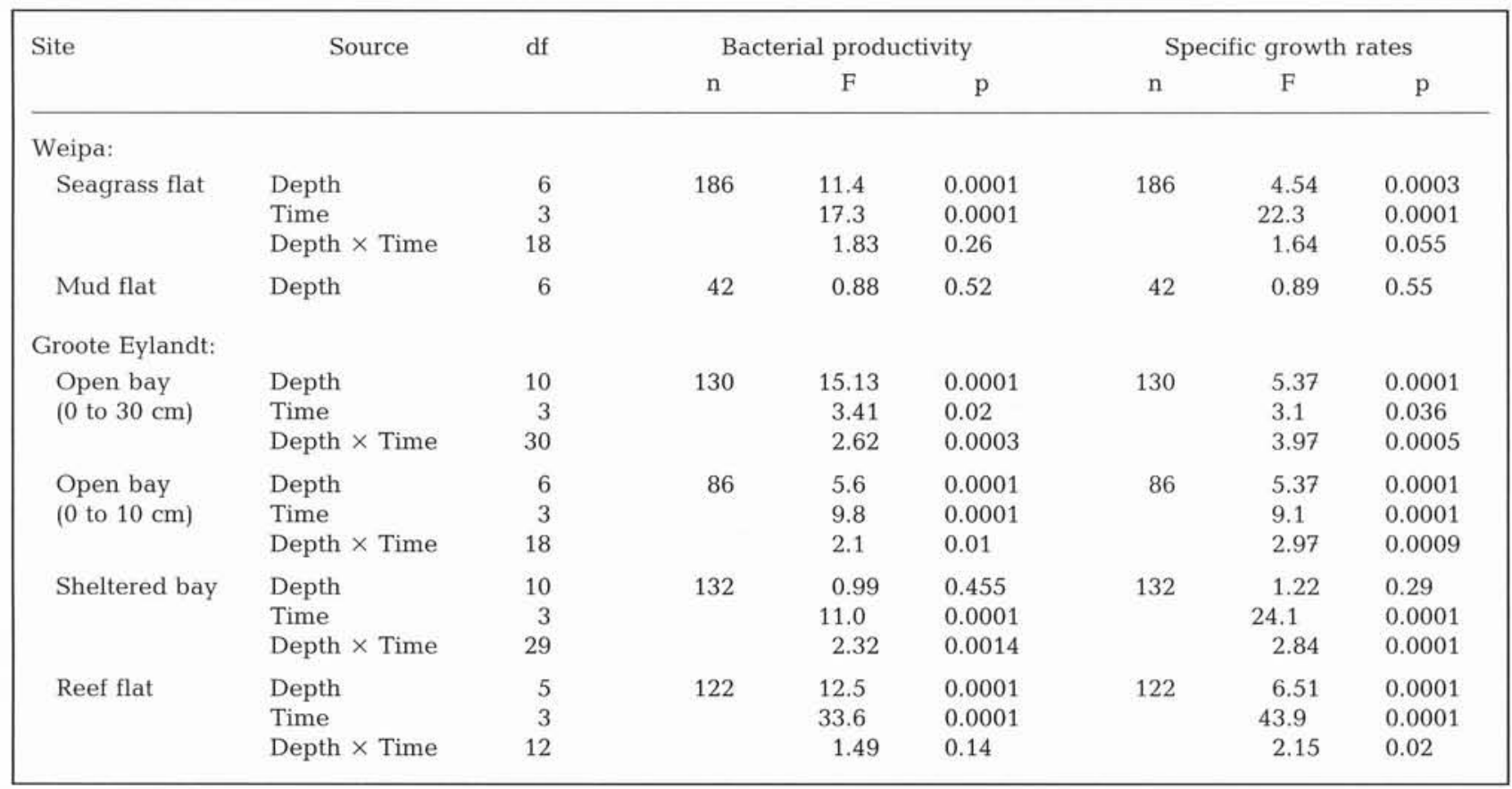




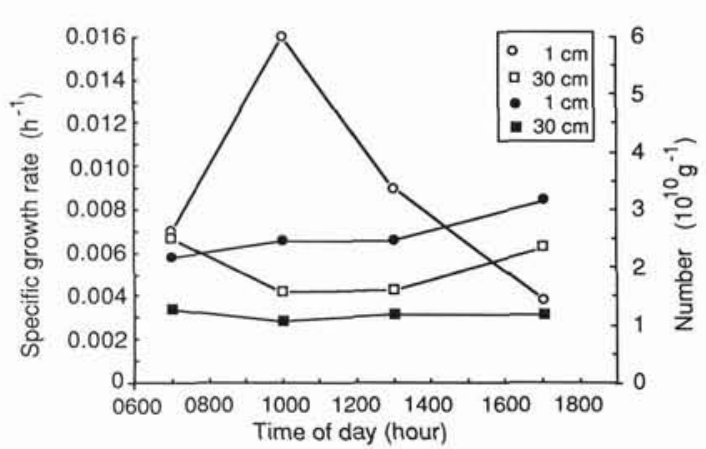

Fig. 3. Diurnal variation in specific growth rates (bacterial productivity divided by bacterial numbers) and numbers of bacteria in sediment at the open bay site, Groote Eylandt. Standard errors of the numbers were 8 to $12 \%$ of the mean values shown. Open symbols: specific growth rate; filled symbols: number

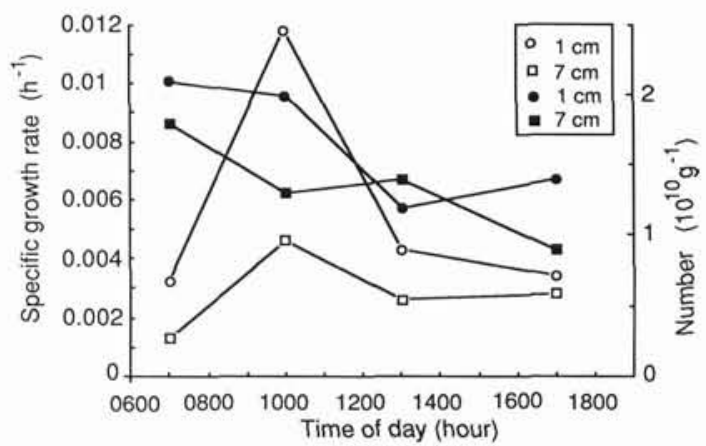

Fig. 4. Diurnal variation in specific growth rates (bacterial productivity divided by bacterial numbers) and numbers of bacteria in sediment on the reef flat, Groote Eylandt. Standard errors of the numbers were 8 to $12 \%$ of the mean values shown. Open symbols: specific growth rate; filled symbols: number

$10 \mathrm{~cm}$ than at $20 \mathrm{~cm}$, probably because most roots and rhizomes were found in the zone between 3 and $10 \mathrm{~cm}$; some roots penetrated to $30 \mathrm{~cm}$ or more (Fig. $5 \mathrm{~b}$ ).

In the sparse Enhalus acoroides bed at Weipa, bacterial productivity and specific growth rates were not significantly different from rates on the nearby mud flat in the same river, where there were no seagrasses (Table 3 , Fig. 6). This suggests the density of seagrasses was too low to observe any influence of the seagrass on bacterial productivities.

\section{Sulphate reduction}

The concentration of sulphate was $30 \mathrm{mM}$ in the interstitial water at each site and depth; thus, sulphate concentration was not limiting sulphate reduction in these sediments. Similar amounts of radioactively labelled hydrogen sulphide and pyrite were produced in most sediment samples. Others researchers have also found large amounts of pyrite formation when measuring sulphate reduction (Howarth \& Merkel 1984, Jørgensen et al. 1990).
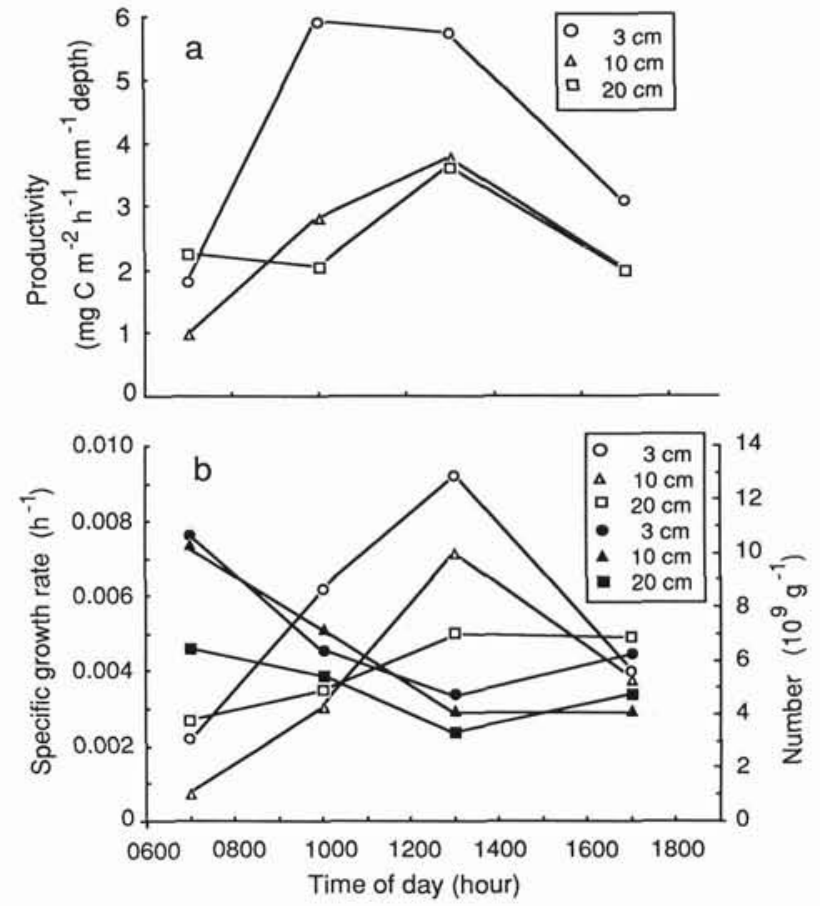

Fig. 5. Diurnal variation in (a) productivity of bacteria, and (b) specific growth rates and numbers of bacteria, in sediment at the sheltered bay site, Groote Eylandt. Standard errors of the numbers were 8 to $12 \%$ of the mean values shown. Open symbols: specific growth rate; filled symbols: number

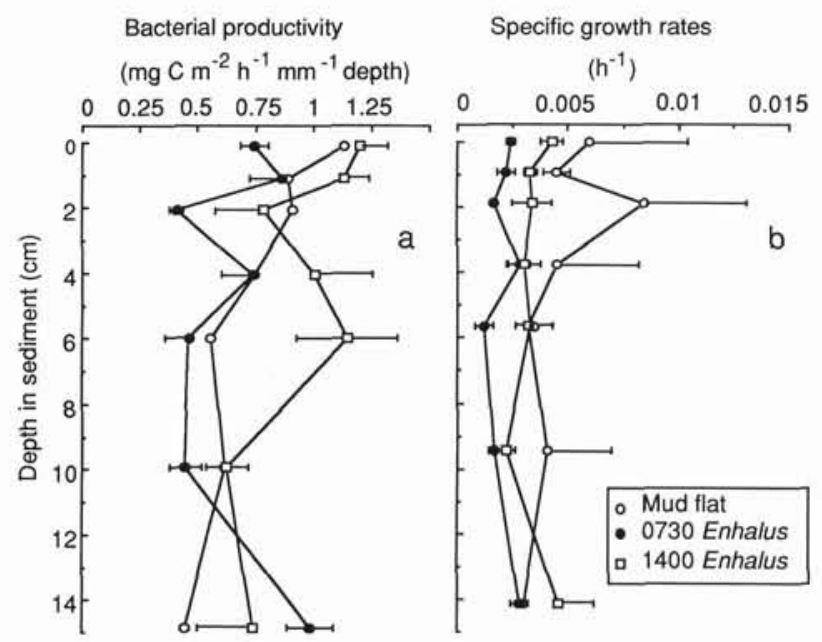

Fig. 6. (a) Bacterial productivity and (b) specific growth rates of bacteria, in sediment at the Weipa study sites. The mud flat was sampled at 14:00 h. For clarity, only the larger error bars are shown; an analysis of variance is given in the text

The sulphate reduction rates were very similar in all the seagrass areas studied. On the mud flat, where there were no seagrasses, rates were 6 times lower and significantly different ( $p<0.0001$, down to $20 \mathrm{~cm}$ ) from the seagrass communities (Table 4). The rates of sulphate reduction in the open bay at Groote Eylandt were 
Table 4. Bacterial productivity and sulphate reduction rates in sediment at Weipa and Groote Eylandt. Bacterial productivity values were integrated from 3 replicates each at 11 depth intervals in the sediment (except the reef flat: 6 intervals), 4 times during the day. Estimates of $\mathrm{C}$ flux through the aerobic and fermentative bacteria are shown as a percentage of net primary production, estimated as $70 \%$ of gross community primary production (\% PP). The total sulphate reduction rate is shown, and the percentage of total sulphide that was acid-volatile (\% AVS). Sulphate reduction values were integrated from 5 replicates each at $5 \mathrm{~cm}$ depth intervals, at 2 times of the day; for each site, the total depth over which values were integrated is shown. Estimates of C flux through the sulphate-reducing bacteria are shown as percentages of $\mathrm{C}$ supplied by heterotrophic bacteria other than sulphate reducers $(\% \mathrm{BP})$ and by primary producers ( $\% \mathrm{PP})$

\begin{tabular}{|c|c|c|c|c|c|c|c|c|}
\hline \multirow[t]{2}{*}{ Site } & \multirow{2}{*}{$\begin{array}{l}\text { Depth } \\
\text { (cm) }\end{array}$} & \multicolumn{2}{|c|}{ Bacterial productivity } & \multicolumn{5}{|c|}{ Sulphate reduction } \\
\hline & & $\mathrm{g} \mathrm{C} \mathrm{m}^{-2} \mathrm{~d}^{-1}$ & $\%$ PP & $\%$ AVS & $\mathrm{mmol} \mathrm{m}{ }^{-2} \mathrm{~d}^{-1}$ & $\mathrm{gCm}^{-2} \mathrm{~d}^{-1}$ & $\%$ BP & $\%$ PP \\
\hline \multicolumn{9}{|l|}{ Weipa } \\
\hline Mud flat & 20 & 3.4 & & 69 & 12 & 0.32 & 10 & \\
\hline Seagrass flat & 20 & 3.5 & 125 & 56 & 90 & 2.2 & 63 & 78 \\
\hline \multicolumn{9}{|l|}{ Groote Eylandt } \\
\hline Sheltered bay & 20 & 4.0 & 114 & 32 & 75 & 1.8 & 45 & 50 \\
\hline Open bay & 10 & 13.0 & 200 & 49 & 61 & 1.7 & 13 & 27 \\
\hline Reef flat & 7 & 3.1 & 75 & 30 & 64 & 1.8 & 60 & 43 \\
\hline
\end{tabular}

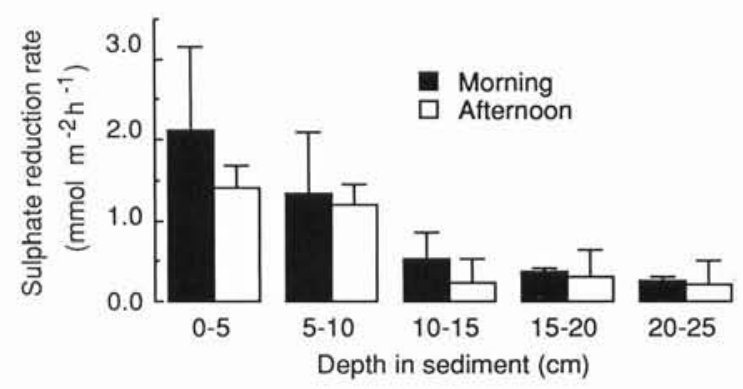

Fig. 7. Rates of sulphate reduction in the sediment of the open bay, Groote Eylandt

significantly higher $(\mathrm{p}<0.001)$ in the top $10 \mathrm{~cm}$ than deeper in the sediment (Fig. 7). The change with depth in the sediment was similar to rates of bacterial production on the same site, with the greatest rates in the top $5 \mathrm{~cm}$ (cf. Figs. 2 \& 7). In the sheltered bay, however, there was no significant variation with depth, probably because the shoot density of Enhalus acoroides was 10 times lower than that of the seagrasses at the open bay site. There was some evidence of a diurnal variation in sulphate reduction in the sheltered bay; sulphate reduction was greater in the afternoon than in the morning ( $p=0.05$, Fig. 8).

\section{DISCUSSION}

\section{Primary production}

Microalgae (epiphytic and benthic) were a major source of primary productivity, even in areas dominated by seagrasses. In the open bay site $50 \%$ of gross

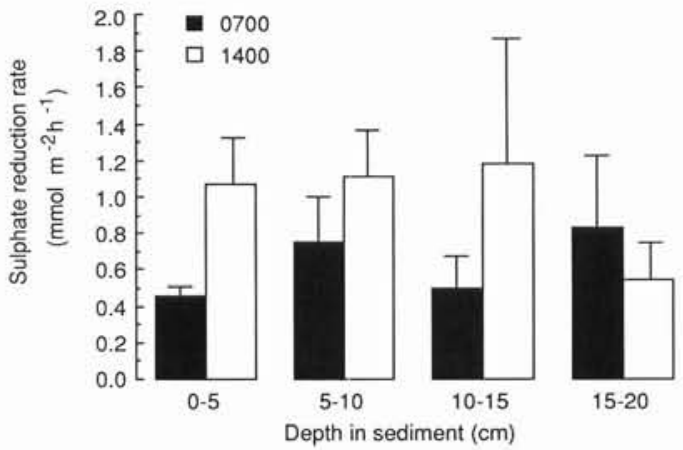

Fig. 8. Rates of sulphate reduction in the sediment of the sheltered bay, Groote Eylandt

community primary productivity was contributed by seagrasses. As there were no macroalgae at this study site, benthic and/or epiphytic microalgae were contributing as much as were seagrasses to community primary productivity. The increase in algal productivity over that observed in 1985 (Moriarty et al. 1990) may have been due to the effects of the cyclone 'Jason'. Bacterial growth and respiration rates were much higher in 1987 than in 1985, suggesting that bacterial remineralisation processes may have made more nutrients available for algal growth.

On the reef flat seagrasses accounted for only $13 \%$ of total community productivity (Table 1 ). Thus, in contrast to sediments where seagrasses are dominant, much of the organic matter that fuels bacterial decomposition processes is derived from algae at the sediment surface.

Epiphytic and epibenthic algae appeared to be important contributors to community primary productivity in the Enhalus acoroides communities at both 
Groote Eylandt and Weipa, but they were more important at Weipa. Our findings suggest that the algae contribute about $40 \%$ (Groote Eylandt) and $80 \%$ (Weipa) of community productivity, but we do not know how this productivity is distributed between epibenthic and epiphytic algae. These observations are consistent with the results of Lindeboom \& Sandee (1989), who reported that $36 \%$ of gross primary productivity was due to epiphytes of the seagrass communities (Thalassia hemprichii and Halodule uninervis) in Indonesia. A similar result was also found by Heijs (1985) in seagrasses of Papua New Guinea.

In previous seasons, at the open bay site, the microalgal contribution to community productivity varied from 0 to $65 \%$ (Moriarty et al. 1990). Others have found that algae are only a minor component of community primary productivity; for example, Brouns \& Heijs (1986) reported that epiphytes of Enhalus acoroides in Papua New Guinea contributed only 2 to $9 \%$ of total aboveground productivity. They also estimated net productivity of $E$. acoroides to be between 18 and $26.4 \mathrm{mg}$ ashfree dry wt shoot ${ }^{-1} \mathrm{~d}^{-1}$, or about 8 to $12 \mathrm{mg} \mathrm{C}$ shoot $^{-1}$ $\mathrm{d}^{-1}$, whereas our mean values for gross productivity were 26 and $45 \mathrm{mg} \mathrm{C}$ shoot ${ }^{-1} \mathrm{~d}^{-1}$ (Table 1). Comparisons of primary productivity measurements taken at different locations and times are difficult to make, because there is a wide variety of available nutrients, temperature, light, salinity conditions and sediment types that influence primary productivity.

\section{Organic carbon flux through bacteria}

To follow carbon flux through bacteria from the primary producers, we have estimated net primary productivity to be $70 \%$ of the gross productivity of seagrasses and algae, based on the work of Buesa (1977). In a $24 \mathrm{~h}$ study of each community, it is difficult to assess the proportion of community primary productivity contributed by bacterial productivity because bacterial productivity measurements include all the organic carbon that has been converted into bacterial biomass, not only from carbon fixed photosynthetically but also from carbon that has been recycled within the bacterial community. However, the amount of organic carbon required to support bacterial metabolism can be estimated from the rates of bacterial productivity if the proportion of organic carbon used for the production of new bacteria biomass (the growth efficiency) is known.

We have assumed growth efficiencies to be $50 \%$, based on a model proposed by Moriarty (1989) which relates bacterial productivity to the rate of organic carbon input. It is assumed that the ecosystem is closed, with no removal of bacterial biomass and no external source of organic carbon. Using this simple model, the average growth efficiency of the bacterial community in the sediment would be between 50 and $60 \%$ when the bacterial productivities were 114 and $125 \%$ of estimated net primary productivity in the Enhalus acoroides beds (Table 4). This estimate is consistent with the literature, where the average efficiency of bacteria has been reported to be between 30 and $50 \%$ (Robinson et al. 1982, Ducklow 1983, Staley \& Konopka 1985). Hence, we suggest that most of the seagrasses and epiphytic and epibenthic algae growing in the sediment were decomposed there.

Sources of organic carbon from outside the seagrass community may also contribute to bacterial productivity, resulting in values that are higher than the primary productivity (Table 4 ). This appeared to be the case at the open bay site, where bacterial productivities and community respiration rates were unusually high compared to those at other sites (Tables 1 \& 4). This suggests there were other sources of organic carbon supporting the bacteria. An allochthonous carbon input may have been the result of the effects of the cyclone 'Jason', which passed Groote Eylandt a week before the study. Physical characteristics of the dense seagrasses may have aided the deposition of suspended particulate organic matter from terrestrial sources or adjacent areas, thus providing additional substrates for bacterial growth.

The high bacterial productivities are consistent with the high respiration rates. If the average growth efficiency of the bacterial community was $50 \%$, their respiration rates would equal productivity, i.e. $13 \mathrm{~g} \mathrm{C}$ $\mathrm{m}^{-2} \mathrm{~d}^{-1}$. As the respiration of the whole community was $11 \mathrm{~g} \mathrm{C} \mathrm{m}^{-2} \mathrm{~d}^{-1}$, it seems that benthic bacteria were responsible for much of it. In fact, at night, $13 \mathrm{~g} \mathrm{C} \mathrm{m}^{-2}$ $\mathrm{d}^{-1}$ would require $35 \mathrm{~g} \mathrm{O}_{2} \mathrm{~m}^{-2} \mathrm{~d}^{-1}$, or $17 \mathrm{~g} \mathrm{O}_{2} \mathrm{~m}^{-2}$. This rate of respiration would deplete all of the oxygen in a water column $2 \mathrm{~m}$ deep, and indeed this almost appeared to be the case (see Table 1).

On the reef flat, bacterial productivity was $75 \%$ of net primary productivity (Table 4 ). This percentage is less than the expected value and may indicate either that the efficiency was less than $50 \%$ or that primary productivity is exported from this site by tides and currents or by grazers. Maximum sediment depth there was $7 \mathrm{~cm}$, and much of the primary productivity was at the sediment surface. Hence it is conceivable that the cyclone may have caused a net loss of primary productivity from the site.

\section{Carbon flux and sulphate reducers}

Ultimately, organic matter that is neither exported from the site nor respired by aerobes (hydrolytic), fermenters and nitrate-reducing bacteria in marine sedi- 
ments is oxidised by the sulphate-reducing bacteria. Measurement of $\mathrm{C}$ flux through sulphate-reducing bacteria provides a minimum estimate of $\mathrm{C}$ flux through heterotrophs. It is independent of estimates derived from the thymidine method, because sulphate-reducing bacteria do not take up thymidine (Moriarty 1986).

Carbon flux through the sulphate-reducing bacteria was 45 to $60 \%$ of that through the other heterotrophs in the seagrass sediments, except for the open bay, where it was $13 \%$ (Table 4). It seems that in the open bay site, which was disturbed by the cyclone, 1 wk was too short a time for the steady state relationships between sulphate-reducing bacteria and the other heterotrophs, on which they depend, to be re-established. However, between 27 and $78 \%$ of net primary productivity was mineralised via the sulphate-reducing bacteria in the seagrass beds. The sulphate-reducing bacteria are the terminal oxidisers, oxidising the organic matter which the other heterotrophic bacteria have not respired. Most of the primary productivity appears to have been oxidised to $\mathrm{CO}_{2}$ by bacteria in the sediments. Similar results have been found for other seagrass beds and coastal and salt-marsh sediments (Howarth \& Teal 1979, Jørgensen 1982, Howarth 1984, Moriarty et al. 1985, Skyring 1987, Canfield 1989). These relationships between primary and bacterial productivities indicate that bacteria, to a large degree, are responsible for the oxidation of most of the organic matter from primary production that is not utilised by higher trophic levels.

\section{Diurnal variation in bacterial activity}

Diurnal increases in bacterial productivity in temperate seagrass beds have been reported earlier (Moriarty \& Pollard 1982). These increases are probably due to the exudation of organic matter by seagrass roots and rhizomes during photosynthesis (Moriarty et al. 1986). A similar conclusion can be drawn from the data presented here. Increases in specific growth rates associated with the sediment surface and the root zones of some of the tropical seagrasses studied here, were observed in the late morning (Figs. 3, 4, \& 5b). At the open bay site on Groote Eylandt, the variance in bacterial productivity due to time of day was greater than that due to depth (Table 3). This indicates that photosynthesis by the seagrass influenced bacterial growth. There was a significant interaction between depth and time of day, indicating that the extent of diurnal variation in bacterial productivity varied with depth in the sediment. This is to be expected where seagrass roots are not distributed evenly throughout the whole sediment profile $(0$ to $30 \mathrm{~cm})$.

However, there was little evidence of a diurnal varia- tion in rates of sulphate reduction. This could be because organic matter resulting from the primary productivity of seagrasses and algae is only slowly transferred to the sulphate-reducing bacteria via general heterotrophic bacteria processes. The nutritional value of the organic material, and the number of steps in its decomposition by the heterotrophic bacteria, determine the rate of metabolism of organic carbon (Mann 1988) to a simple form, e.g acetate, capable of being utilised by sulphate-reducing bacteria (Skyring 1988). There was no direct link between the sulphate reduction rates and photosynthetic activity, because these processes are separated temporally and spatially by other bacterial processes. There is further evidence of this delay at the open bay site, where there was no increase in the sulphate-reduction rates concomitant to the dramatic increases in bacterial activity, as measured by the thymidine method (Table 4 ).

Organic carbon transfer from primary producers to heterotrophic bacteria has been based on an estimate of the amount of carbon recycled within the bacterial community. To understand more clearly how carbon flow from primary producers might regulate decomposition, primary and bacterial productivity need to be measured at frequent intervals over months or days, rather than in a single day.

Acknowledgements. We thank Georgina Davis for her assistance in measuring seagrass productivity and counting bacteria, and for constructing a protective net. The sulphate analysis was conducted by the Queensland Government Chemical Laboratory, Brisbane, Queensland, Australia. This work was supported by grant No. 1986/78 from the Fishing Industry Research Trust Account, and by Marine Sciences and Technologies grant No. 81/0319. We are grateful to Dr G. W. Skyring, CSIRO Division of Water Resources, Canberra, for his advice and assistance with the sulphate reduction analyses; to Dr J. D. Kerr, CSIRO, who has kindly given advice on the statistical analyses; and to Dr Paul Boon for his self-sacrifice in reviewing this manuscript.

\section{LITERATURE CITED}

Alongi, D. M. (1988). Bacterial productivity and microbial biomass in tropical mangrove sediments. Microb. Ecol. 15: 59-79

Boynton, W. R., Kemp, W. M. (1985). Nutrient regeneration and oxygen consumption by sediments along an estuarine salinity gradient. Mar. Ecol. Prog. Ser. 23: 45-55

Bratbak, G., Dundas, I. (1984). Bacterial dry matter content and biomass estimations. Appl. environ. Microbiol. 48 (4): 755-757

Brouns, J. W. M., Heijs, F. M. L. (1986). Production and biomass of the seagrass Enhalus acoroides (L.F.) Royle and its epiphytes. Aquat. Bot. 25: 21-45

Buesa, R. J. (1977). Photosynthesis and respiration of some tropical marine plants, Aquat. Bot 3: 203-216

Canfield, D. E. (1989). Sulphate reduction and oxic respiration in marine sediments: implications for organic carbon pre- 
servation in euxinic environments. Deep Sea Res. 36: 121-138

Caraco, N. F., Cole, J. J., Likens, G. E. (1989). Evidence for sulphate-controlled phosphorous release from sediments of aquatic systems. Nature, Lond. 341: 316-318

Craven, P. A., Hayaska, S. S. (1982). Inorganic phosphate solubilisation by rhizosphere bacteria in a Zostera marina community. Can. J. Microbiol. 28: 605-610

Ducklow, H. W. (1983). The production and fate of bacteria in the oceans. BioSci. 33: 494-501

Findlay, S., Carlough, L., Crocker, M. T., Gill, H. K., Meyer, J. L., Smith, P. J. (1986). Bacterial growth on macrophyte leachate and fate of bacterial production. Limnol. Oceanogr. 31 (6): 1335-1341

Heijs, F. M. L. (1985). Some structural and functional aspects of the epiphytic component of four seagrass species (Cymodoceideae) from Papua New Guinea. Aquat. Bot. 23: 225-247

Hobbie, J. E., Daley, R. J., Jasper, S. (1977). Use of Nuclepore filters for counting bacteria by fluorescence microscopy. Appl. environ. Microbiol. 33: 1225-1228

Howarth, R. W. (1984). The ecological significance of sulfur in the energy dynamics of salt marsh and coastal marine sediments. Biogeochemistry 1: 5-27

Howarth, R. W., Marino, R., Cole, J. J. (1988a). Nitrogen fixation in freshwater, estuary and marine ecosystems. 1. Rates and importance. Limnol. Oceanogr. 33: 669-687

Howarth, R. W., Marino, R., Cole, J. J. (1988b). Nitrogen fixation in freshwater, estuary and marine ecosystems. 2. Biogeochemical controls. Limnol, Oceanogr. 33: 669-687

Howarth, R. W., Merkel, S. (1984). Pyrite formation and measurement of sulphate reduction in salt marsh sediments. Limnol. Oceanogr. 29: 598-608

Howarth, R. W., Teal, J. M. (1979). Sulfate reduction in a New England salt marsh. Limnol. Oceanogr. 24: 999-1013

Jørgensen, B. B. (1982). Mineralization of organic matter in the sea bed - the role of sulphate reduction. Nature, Lond. 296: 643-645

Jørgensen, B. B., Zawacki, L. X., Jannasch, H. W. (1990). Thermophilic bacterial sulphate reduction in deep-sea sediments at Guaymas Basin hydrothermal vent site (Gulf of California). Deep Sea Res. 37: 695-710

Lindeboom, H. J., Sandee, A. J. J. (1989). Production and consumption of tropical seagrass fields in eastern Indonesia measured with bell jars and microelectrodes. Neth. J. Sea Res. 23: 181-190

Mann, K. H. (1988). Production and use of detritus in various freshwater, estuarine, and coastal marine ecosystems. Limnol. Oceanogr. 33: 910-930

Moriarty, D. J. W. (1986). Measurement of bacterial growth rates in aquativ-systems from rates of nucleic acid synthesis. Adv. Microb. Ecol. 9: 245-292

Moriarty, D. J, W, (1988). Accurate conversion factors for calculating bacterial growth rates from thymidine incorporation into DNA: elusive or illusive? Arch. Hydrobiol. Ergebn. Limnol. 31: 211-217

Moriarty, D. J. W. (1989). Relationships of bacterial biomass and production to primary production in marine sediments. In: Hattori, T., Ishida, Y., Maruyama, Y., Morita, R. Y., Uchida, A. (eds.) Recent advances in microbial ecology. Japanese Scientific Societies Press, Tokyo, p. 349-354

This article was presented by Dr G. F. Humphrey, Sydney, Australia
Moriarty, D. J. W., Pollard, P. C. (1982). Diel variation of bacterial productivity in seagrass (Zostera capricorni) beds measured by rate of thymidine incorporation into DNA, Mar. Biol. 72: 165-173

Moriarty, D. J. W., Pollard, P. C. (1990). Effects of radioactive labelling of macromolecules, disturbance of bacteria and adsorption of thymidine to sediment on the determination of bacterial growth rates in sediment with tritiated thymidine. J. microbiol. Meth. 11: 127-139

Moriarty, D. J. W., Boon, P. I., Hansen, J. A., Hunt, W. G., Poiner, I. R., Pollard, P. C., Skyring, G. W., White, D. C. (1985). Microbial biomass and productivity in seagrass beds. Geomicrobiol. J. 4: 21-51

Moriarty, D. J. W., Iverson, R., Pollard, P. C. (1986). Exudation of organic carbon by the seagrass Halodule wrightii and its effect on bacterial growth in the sediment. J. exp. mar. Biol. Ecol. 96: 115-126

Moriarty, D. J. W., Roberts, D. G., Pollard, P. C. (1990). Primary and bacterial productivity of tropical seagrass communities in the Gulf of Carpentaria, Australia. Mar. Ecol. Prog. Ser. 61: $145-157$

Odum, H. T., Hoskin, C. M. (1958). Comparative studies on the metabolism of marine waters. Publs. Inst. mar. Sci. Univ, Tex. 5: 16-46

Poiner, I. R., Staples, D. J., Kenyon, R. (1987). Seagrass communities of the Gulf of Carpentaria, Australia. Aust. J. mar. Freshwat. Res. 38: 121-131

Pollard, P. C. (1987). Dialysis: a simple method of separating labelled bacterial DNA and tritiated thymidine from aquatic sediments. J. microbiol. Meth. 7: 91-101

Pollard, P. C., Moriarty, D. J. W. (1984). Validity of isotope dilution of tritiated thymidine during incorporation into DNA as an estimate of bacterial growth rates. Appl. environ. Microbiol. 48: 1076-1083

Roberts, D. G., Moriarty, D. J. W. (1987). Lacunal gas discharge as a measure of productivity in the seagrasses Zostera capricornii, Cymodocea serrulata and Syringodium isoetifolium. Aquat. Bot. 28: 143-160

Robinson, J. D., Mann, K. H., Novitsky, J. A. (1982). Conversion of the particulate fraction of seaweed detritus to bacterial biomass. Limnol. Oceanogr. 27: 1072-1079

Skyring, G. W. (1987). Sulfate reduction in coastal ecosystems. Geomicrobiol. J. 5: 295-374

Skyring, G. W. (1988). Acetate as the main energy substrate for the sulfate-reducing bacteria in Lake Eliza (South Australia) hypersaline sediments. FEMS Microbiol. Ecol. 53: $87-94$

Skyring, G. W., Chambers, L. A., Bauld, J. (1983). Sulfate reduction in sediments colonized by cyanobacteria, Spencer Gulf, South Aust. Aust. J. mar. Freshwat. Res. 34: 359-374

Staley, J. T., Konopka, A. (1985). Measurement of in situ activities of nonphotosynthetic microorganisms in aquatic and terrestrial habitats. A. Rev. Microbiol. 39: 321-346

Staples, D. J., Vance, D. J., Heales, D. S. (1985). Habitat requirements of juvenile penaeid prawns and their relationship to offshore fisheries. In: Rothlisberg, P. C., Hill, B. J., Staples, D. J. (eds.) Second Australian National Prawn Seminar. NPS2, Brisbane, p. 47-54

Valiela, I. (1984). Marine ecological processes. In: Reichle, D. E. (ed.) Nutrient cycles: phosphorus, nitrogen, and sulfur. Springer-Verlag, New York, p. 312-341

Manuscript first received: July 10, 1990

Revised version accepted: September 24, 1990 